\title{
SCIDiC
}

\author{
International Journal of Dentistry and Oral Science (IJDOS) \\ ISSN: 2377-8075
}

\section{Soft Tissue Cephalometric Standards for a Moroccan Teenage Population}

Research Article

EL Kaki S, Ousehal L*

Faculty of Dentistry, Department of Orthodontics, Casablanca, Morocco.

Abstract

Objectives: The goal of this study was to assess the soft tissue measurements of Moroccan adolescents with balanced facial profile and correct occlusion and to compare them with other ethnicities norms.

Methods: The material included the lateral cephalometric radiographs of 64 patients, 30 boys and 34 girls, aged between 14 and 18 , with correct occlusion, balanced facial profile, and no subsequent orthodontic treatment. Seven reference lines were identified and traced, on each radiograph, according to Ricketts and Holdaway norms. Twelve linear and 2 angular measurements were analyzed.

Results: Only the $\mathrm{H}$ angle shows a significant difference between boys and girls in our sample. The standards set on the American population and the jordanian one showed several statistically significant differences in comparison with ours.

Conclusion: The results of this study show several differences between the Moroccan soft tissue profile norms and those of their American and jordanian counterparts and strength the idea that the norms of a specific population should be used as a reference for a successful orthodontic treatment.

Keywords: Soft Tissue; Cephalometrics; Teenage.

Abbreviations: AEC: Automatic Exposure Control; STF: Soft Tissue Facial; SN: Sella-Nasion; HTF: Hard Tissue Facial; FP: Frankfort Perpendicular.

\section{Introduction}

The orthodontic treatment aims the restoration of stable and functional occlusion as well as harmonious skeletal proportions in a balanced face. Thus, the orthodontist must give similar attention to the facial or profile soft tissues, the maxillary and mandibular bone bases, and the dento-dental ratios. Soft tissue analysis is an integral part of the facial examination and constitutes a major decision-making element which is as important as the cephalometric dento-skeletal analysis during the setting of the diagnosis and orthodontic treatment plan [1,2]. The naso-labial angle, the thickness of the lips, and the anteroposterior and vertical position of the chin are all elements that must be taken into consideration to establish the treatment plan.

The importance of soft tissues and in the orthodontic diagnosis and treatment was raised since Angle in 1907. In fact, Angle noted that the soft tissues were an important factor in face harmony, which can affect the psychological development of the young [3]. This idea was supported by Holdaway who found that the results would be better when the factor "soft tissue" of the face was taken into account [4]. Besides, he emphasized that appropriate proportions of soft tissues were compatible with the harmonization of facial lines.

However, this concept of facial aesthetics is difficult to define because it contains variability factors related to culture, beauty ideals and fashions.

Similarly to the conventional cephalometric analysis, American authors have suggested profile cephalometric standards that must be attained for an ideal orthodontic treatment; Holdaway 1956, 1983 [4, 5]; Ricketts (1957) [6]; Burstone (1959) [7]. The problem lies in the application of these standards to other populations.

Due to the fact that there are ethnic differences that make each

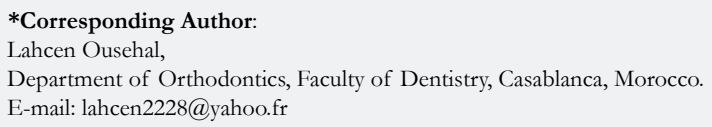

Copyright: Ousehal $\mathbf{L}^{\circ}$ 2018. This is an open-access article distributed under the terms of the Creative Commons Attribution License, which permits unrestricted use, distribution and reproduction in any medium, provided the original author and source are credited. 
population soft tissue profile different, restoring our patients profile to a North American or average Australian profile is probably a mistake.

According to the statistics provided by the Consular and Social Affairs head office of the Moroccan Ministry of Foreign Affairs and Cooperation, $10 \%$ of Moroccans live abroad, which makes more than 3 million people. This migration flow interests more particularly European countries, as European orthodontists will have to deal with Moroccan patients in their offices [8].

Orthodontic literature contains several studies involving soft tissue cephalometric standards and the profile of adolescent patients from all over the world, Caucasians and Afro-Americans, Americans and Mexicans, Japanese, Chinese, Filipinos, Koreans, Anatolian Turks..., but little published data for Arabs. In fact, up to the time of the writing of these lines, no study has attempted to assess the cephalometric standards of the profile soft tissue of the Moroccan population.

The main aim of the present work was to establish the profile cephalometric standards of the facial soft tissues in a sample of Moroccan teenagers with balanced features and a correct occlusion. The secondary aim of this work was to compare our results with the other populations standards.

\section{Methods}

Our study focused on Moroccan adolescents from the great province of Casablanca 10 schools, representing the ten districts of the city as it is geographically divided, were randomly selected. 450 adolescents were randomly selected among 4553 high school students.

The following criteria were used for selection of the sample, balanced features, a normal profile, angle Class I occlusal relationship with normal overbite and overjet and no history of previous orthodontic treatment.
From the 450 selected teens, only 64 met the inclusion criteria. The sample was evenly distributed, according to gender, to 30 boys and 34 girls. Informed consent were obtained from the selected participants.

Ethical approval was obtained from the ethical committee of the establishment.

Lateral radiographs were taken in a private radiology clinic in Casablanca. The unit used was the ORTHORALIX 9200 DDE type with an option of digital GENDEX teleradiography containing three positioning laser beams, a sensor, the VIXWIN PRO software and an automatic control of the (AEC) exposure. The participants were positioned in the cephalostat respecting the parallelism between the Frankfort plane and the floor, the main beam was perpendicular to the sagittal median plane, the patient in occlusion and the lips in rest position.

Bias due to fatigue were eliminated by tracing, only 5 lateral radiographs on average, a day. To eliminate inter-investigator variability, all radiographs were analyzed by a single investigator. The intrainvestigator error was assessed by retracing, twice, 20 randomly selected cephalograms [9].

To assess the skin profile, we used Holdaway and Ricketts analysis using 12 linear measurements and 2 angular measurements in order to identify and trace the 7 reference lines: (Figure 1) Ricketts' $H$ line (Harmony line drawn tangent to the chin and the upper lip, SellaNasion (SN) line, soft tissue facial (STF) line which is a line joining the intersection of the S-Na line with the skin profile and the Pogonion soft tissue, hard tissue facial plane (HTF) drawn from nasion to bony pogonion, the Frankfort plane, the Frankfort perpendicular (FP) line which is a line perpendicular to Frankfort plane and tangent to the vermilion border of the upper lip and Ricketts' E line drawn from the soft tissue pogonion to the tip of the nose [1].

The angular measurements carried out where the soft tissue facial

Figure 1. Ricketts's and Holdaway's analysis used in our study.

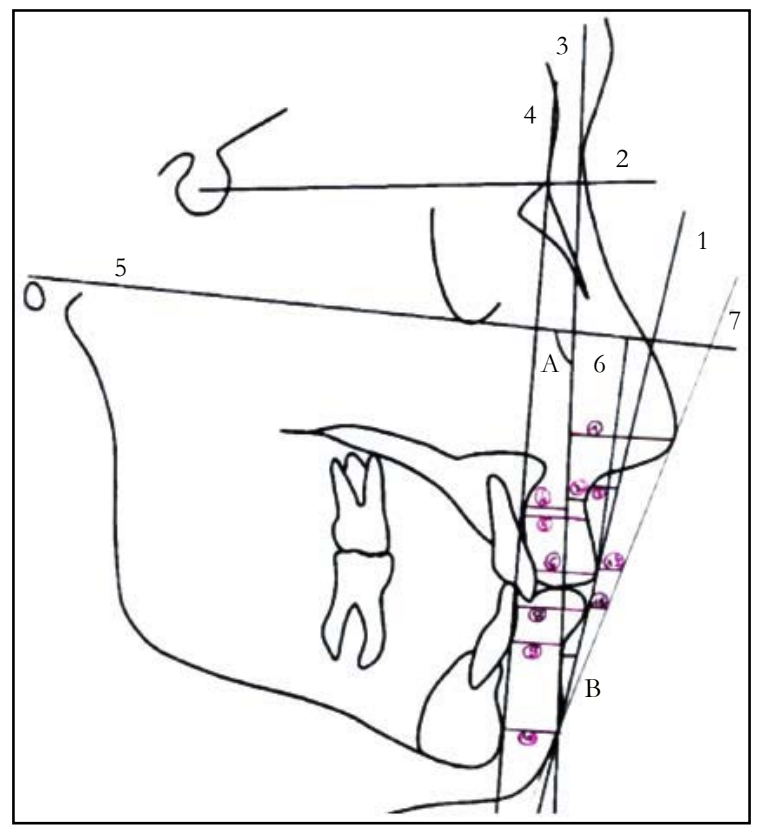


angle formed by the STF line and the Frankfort plane and the $\mathrm{H}$ angle formed by the $\mathrm{H}$ line and the STF line.

The linear measurements carried out where the nose prominence, from the tip of the nose to the FP line, the superior sulcus depth from the deepest concavity of the upper lip to the FP line, the soft tissue subnasale to $H$ line, the skeletal profile convexity from A point to the STF line, the basic upper lip thickness which is the distance between the upper lip and a point $3 \mathrm{~mm}$ below the A point of Downs, the upper lip thickness from the vermilion border of the upper lip to the labial surface of the maxillary incisor, the upper lip strain which is the difference between basic upper lip thickness and upper lip thickness, the lower lip to $H$ line from the vermilion border of the lower lip to the $\mathrm{H}$ line, the distance is positive $(+)$ if the lower lip is in front of the $\mathrm{H}$ line and negative $\left(_{-}\right)$otherwise, the inferior sulcus depth from the point of greatest concavity of the lower lip to the $\mathrm{H}$ line, the soft tissue chin thickness which is the pogonion-facial plane distance, the labrale inferius from the most anterior point of the lower lip to Ricketts' E line and the Labrale superius which is the distance from the most anterior point of the upper lip to Ricketts' $\mathrm{E}$ line. The distance is positive $(+)$ if the lips are in front of the $\mathrm{E}$ line and negative $(-)$ otherwise [1].

The key-boarding and the statistical analysis of the results were carried out using the Epi Info 6.0 software.

\section{Results}

The measurements were statistically analyzed by calculating their means and standard deviations. Then the mean values of the moroccan population were compared with mean values of jordanian and american population with the help of Student's unpaired ' $t$ ' test and 'P' value of $\leq 0.05$ was considered statistically significant.

The participants in our sample were aged between 14 and 18 years old, with an average age of 16.5 years and a standard deviation of 0.6 years. $53 \%$ of our sample is female.
Table 1 illustrates the gender differences of soft tissue variables; no statistically significant differences are noticed except for one variable; moroccan males revealed a greater $\mathrm{H}$ angle with an average of 2.54 degrees in comparison with girls. We can, therefore, conclude that the girls and boys in our study had the same soft tissue profile standards.

The facial skin angle and the distance between the most anterior point of the upper lip and Rickett's line were the only significant difference. In fact, Moroccans had a facial skin angle more open with 6.68 degrees and an upper lip recessed with an average of $2.33 \mathrm{~mm}$ compared to Jordanians [10] (Table 2).

Moroccans had a facial skin angle greater with 3.18 degrees, and the same is true for the $\mathrm{H}$ angle and the bony convexity which were greater with 5 degrees and $3 \mathrm{~mm}$ respectively compared to the American standards. The thickness of the chin skin represented by the pogonion-facial plane distance was greater with an average of $2.53 \mathrm{~mm}$ compared to the Americans (Table 3).

Other values showed no statistically significant difference.

\section{Discussion}

Despite the fact that the Kingdom of Morocco is one of the main countries in North Africa belonging to the Arab Maghreb, no study in the world has ever attempted to determine the tissue cephalometric standards of this ethnic entity. Thus, this study has come to fill in this gap and draw a table of the average tissue cephalometric values in this region (Table 1).

Our results showed that the only statistically significant difference between men and women in our sample was the $H$ angle [1]. The latter was significantly greater in boys with $2.54^{\circ}$, which indicates that Moroccan males had a more prominent upper lip compared to women [1]. This is consistent not only with the results found in

Table 1. Statistical comparison of Soft Tissue Cephalometric norms between fameles and males in our study.

\begin{tabular}{|c|c|c|c|c|c|}
\hline \multirow{2}{*}{ Parameter } & \multicolumn{2}{|c|}{ Females $(n=34)$} & \multicolumn{2}{|c|}{ Males $(n=30)$} & \multirow{2}{*}{$\begin{array}{c}\text { Difference } \\
\text { (M) }\end{array}$} \\
\hline & Mean & SD & Mean & SD & \\
\hline Soft tissue facial angle $\left(^{\circ}\right)$ & 94.47 & 3.21 & 93.89 & 3.24 & 0.58 \\
\hline $\mathrm{H}$ angle $\left(^{\circ}\right)$ & 13.73 & 2.75 & 16.27 & 2.56 & -2.54 \\
\hline Nose prominence $(\mathrm{mm})$ & 17.76 & 2.45 & 19.63 & 3.01 & -1.87 \\
\hline Superior sulcus depth (mm) & 3.05 & 2.22 & 3.3 & 1.56 & -0.2 \\
\hline Subnasale to $\mathrm{H}$ line $(\mathrm{mm})$ & 4.39 & 2.02 & 5.16 & 2.45 & -0.77 \\
\hline Skeletal profile convexity $(\mathrm{mm})$ & 2.97 & 1.45 & 3.03 & 3.02 & -0.06 \\
\hline Basic upper lip thickness (mm) & 14.17 & 1.57 & 15.93 & 2.02 & -1.76 \\
\hline Upper lip thickness $(\mathrm{mm})$ & 13.71 & 2.01 & 14.89 & 2 & -1.18 \\
\hline Upper lip strain (mm) & 1.7 & 2.08 & 1.82 & 1.45 & -0.12 \\
\hline Lower lip to $\mathrm{H}$ line $(\mathrm{mm})$ & -1.7 & 2.44 & -1.06 & 2.26 & -0.64 \\
\hline Inferior sulcus to $\mathrm{H}$ line $(\mathrm{mm})$ & 4.26 & 1.56 & 4.72 & 2.34 & -0.46 \\
\hline Soft tissue chin thickness $(\mathrm{mm})$ & 13.46 & 1.02 & 13.6 & 1.24 & -0.16 \\
\hline Labrale inferius to $\mathrm{E}$ line $(\mathrm{mm})$ & -2.61 & 3.01 & -1.79 & 3.22 & -0.82 \\
\hline Labralesuperius to E line (mm) & -2.41 & 2.01 & -2.13 & 1.67 & -0.4 \\
\hline
\end{tabular}

* Significant difference at $\mathrm{P}<0.05$ (independent sample $t$-test) 
Table 2 : Statistical comparison of Soft Tissue Cephalometric norms between Jordanian and Moroccan population.

\begin{tabular}{|c|c|c|c|c|c|c|}
\hline \multirow[t]{2}{*}{ Parameter } & \multicolumn{2}{|c|}{$\begin{array}{c}\text { Moroccan Norms } \\
\qquad(n=64)\end{array}$} & \multicolumn{2}{|c|}{$\begin{array}{l}\text { Jordanian Norms } \\
\qquad(\mathrm{n}=41)\end{array}$} & \multirow[t]{2}{*}{$\begin{array}{l}\text { Difference } \\
\text { (Mean) }\end{array}$} & \multirow[t]{2}{*}{$\begin{array}{l}\text { Significant } \\
\text { difference }\end{array}$} \\
\hline & Mean & SD & Mean & SD & & \\
\hline Soft tissue facial angle $\left(^{\circ}\right)$ & 94.18 & 3.21 & 87.5 & 3.84 & 6.68 & $\mathrm{~S}^{*}$ \\
\hline $\mathrm{H}$ angle $\left(^{\circ}\right)$ & 15 & 2.75 & 15.04 & 4.54 & -0.4 & NS \\
\hline Nose prominence $(\mathrm{mm})$ & 18.69 & 2.45 & 16.5 & 3.16 & 2.19 & NS \\
\hline Superior sulcus depth (mm) & 3.17 & 2.22 & 3 & 1.43 & 0.17 & NS \\
\hline Subnasale to $\mathrm{H}$ line $(\mathrm{mm})$ & 4.77 & 2.02 & 5.4 & 2.66 & -0.63 & NS \\
\hline Skeletal profile convexity (mm) & 3 & 1.45 & 3.2 & 2.04 & -0.2 & NS \\
\hline Basic upper lip thickness (mm) & 15.05 & 1.57 & 14.9 & 2.27 & 0.15 & NS \\
\hline Upper lip thickness (mm) & 14.3 & 2.01 & 14 & 2.26 & 0.3 & NS \\
\hline Upper lip strain (mm) & 1.76 & 2.08 & 0.9 & 1.46 & 0.86 & NS \\
\hline Lower lip to $\mathrm{H}$ line $(\mathrm{mm})$ & -1.38 & 2.44 & -0.2 & 1.6 & -1.18 & NS \\
\hline Inferior sulcus to $\mathrm{H}$ line $(\mathrm{mm})$ & 4.49 & 1.56 & 5.4 & 2.47 & -0.91 & NS \\
\hline Soft tissue chin thickness (mm) & 13.53 & 1.02 & 12.8 & 1.92 & 0.73 & NS \\
\hline Labrale inferius to E line (mm) & -2.2 & 3.01 & -2.2 & 2.6 & 0 & NS \\
\hline Labrale superius to $\mathrm{E}$ line (mm) & -2.27 & 2.01 & -4.6 & 2.78 & 2.33 & $\mathrm{~S}^{*}$ \\
\hline
\end{tabular}

* Significant difference at $\mathrm{P}<0.05$ (independent sample t-test)

Table 3. Statistical comparison of Soft Tissue Cephalometric norms between Moroccan and American population.

\begin{tabular}{|c|c|c|c|c|c|c|}
\hline \multirow[b]{2}{*}{ Parameter } & \multicolumn{2}{|c|}{ Moroccan Norms } & \multicolumn{2}{|c|}{ American Norms } & \multirow{2}{*}{$\begin{array}{l}\text { Difference } \\
\text { (Mean) }\end{array}$} & \multirow{2}{*}{$\begin{array}{l}\text { Significant } \\
\text { difference }\end{array}$} \\
\hline & Mean & SD & Mean & $\begin{array}{c}\text { Uper and } \\
\text { lower values }\end{array}$ & & \\
\hline Soft tissue facial angle $\left({ }^{\circ}\right)$ & 94.18 & 3.21 & 91 & $84-98$ & 3.18 & $\mathrm{~S}^{*}$ \\
\hline H angle $\left(^{\circ}\right)$ & 15 & 2.75 & 10 & $7-14$ & 5 & $\mathrm{~S}^{*}$ \\
\hline Nose prominence $(\mathrm{mm})$ & 18.69 & 2.45 & 19 & $14-24$ & -0.31 & NS \\
\hline Superior sulcus depth (mm) & 3.17 & 2.22 & 3 & $1-4$ & 0.17 & NS \\
\hline Subnasale to $\mathrm{H}$ line $(\mathrm{mm})$ & 4.77 & 2.02 & 5 & $3-7$ & -0.23 & NS \\
\hline Skeletal profile convexity (mm) & 3 & 1.45 & 0 & 0 & 3 & $\mathrm{~S}^{*}$ \\
\hline Basic upper lip thickness (mm) & 15.05 & 1.57 & 15 & 15 & 0.05 & NS \\
\hline Upper lip thickness (mm) & 14.3 & 2.01 & 14 & $13-14$ & 0.3 & NS \\
\hline Upper lip strain (mm) & 1.76 & 2.08 & 1 & 1 & 0.76 & NS \\
\hline Lower lip to $\mathrm{H}$ line $(\mathrm{mm})$ & -1.38 & 2.44 & 0 & $-1-2$ & -1.38 & NS \\
\hline Inferior sulcus to $\mathrm{H}$ line (mm) & 4.49 & 1.56 & 5 & 5 & -0.51 & NS \\
\hline Soft tissue chin thickness (mm) & 13.53 & 1.02 & 11 & $10-12$ & 2.53 & $\mathrm{~S}^{*}$ \\
\hline Labrale inferius to $\mathrm{E}$ line $(\mathrm{mm})$ & -2.2 & 3.01 & -2 & -2 & -0.2 & NS \\
\hline Labrale superius to E line (mm) & -2.27 & 2.01 & -4 & -4 & 1.73 & NS \\
\hline
\end{tabular}

* Significant difference at $\mathrm{P}<0.05$ (independent sample t-test).

the Jordanian population with a difference of $5.4^{\circ}$ in the $\mathrm{H}$ angle between men and women [10], but also with the results found in the Saudi population by Sahar in 2012 [1]. Otherwise, Huda M. Abu-Tayyem, in an Emirati population [11], and Ahmet Arif Celebi in a turkish one, showed that females had a more convex facial profile than males. However, these studies have found out other statistically significant differences according to gender, especially a greater prominence of the nose in males compared to females, a lower lip more retrusive in females than males [12]. Ahangar Atashi, and Taki AA in two other studies on Iranians, noses were more prominent in Iranian men compared to women, In Saudis, males showed significant upper lip thickness and non-significant $[13,14]$.

Other studies, such as Hwang on a Korean population [15], Sugiyama on a Japanese population [16], Johannsdottir on Icelandic patients [17], and Ebray [18] and Basciftci [19] in Anatolian on Turks, have found no difference based on gender.

While comparing the Moroccan norms with other ethnic groups, 
our study showed that compared to Jordanians (Table 2), the Moroccan adolescents have a more open facial skin angle and a more retracted upper lip. However, the comparison with the American norms (Table 3) shows several differences with our sample. In fact, the facial skin angle, the $\mathrm{H}$ angle, the nasal prominence and the thickness of the chin skin were significantly greater in Moroccan adolescents.

These results were consistent with literature that showed that, compared to American standards, the $\mathrm{H}$ angle seems to be greater for Japanese [16], they are also consistent with the study conducted by Lahlou and Col on a balanced adult Moroccan population [20]. In fact, Moroccans had bimaxillary protrusion and, therefore, a more convex skin profile compared to Americans and Caucasians.

Moldez has conducted a similar study among Filipinos. The study focused on 157 patients, 78 of whom were men and 79 were women. The results showed that, compared to American standards, the Filipinos had a more important dental and labial biprotrusion. This brings them closer to our sample [21].

Behbehani F. compared the standards of Kuwaiti teenagers with those of Caucasian teens. These results are consistent with those of our study, as Kuwaiti teenagers have thicker lips and a more convex profile compared to Caucasians [22].

In his study conducted on Ivorian patients, N'Dindin-Guinan BA reported that black Africans had a more convex profile, a labial biprotrusion and a nasolabial angle sharply closed compared to Caucasians [23]. Similar results were found by Moate SJ who demonstrated that the Chinese had a less protrusive nose, a more closed nasolabial angle and a steeper labial protrusion compared to Caucasians [24].

Abbassy A, Horiuchi et al, in their comparative cephalometric study of Class I malocclusion in Egyptian and Japanese adult females, according to Burstone and Ricketts analysis, have reported a more protrusive noise and a less protrusive lips in the egyptian population [25].

In their study conducted on chinese young patients at age 13, Zhao et al., reported a more convex profil, and a less protrusive noise and chin compared to Bolton standards [26].

AMINI F. et al., have reported, in a study on iranian adults, that the Holdaway norms can be used for the Iranian population except for the following measurements: facial convexity angle, nasolabial angle, interlabial gap, soft tissue facial angle, skeletal profile convexity, $\mathrm{H}$-angle, lower lip to $\mathrm{H}$-line, lower sulcus depth, and soft tissue chin thickness [27].

Noor Shaheera Abdul Aziz et al., in a study on Malaysian Chinese population, have reported Statistically significant disparities in the lower lip to s-line, upper lip thickness and Z-angle compared to Caucasian standards [28].

On the other hand, Scavone et al., have conducted a study of profile soft tissues in white Brazilian adults. They demonstrated differences with the American norms. In fact, Brazilian women had an upper and lower lip retrusion and a less pronounced forward projection of the nose compared to the Americans. Brazilian men, however, showed no significant difference with their American counterparts except for the nasal projection which was less important in Brazilians [29]. The same conclusions were made by Kilic $\mathrm{N}$ for Turkish adolescents, who had features more retrusive than North Americans. The skeletal as well as the profile results were compared with Mac Namara's norms [30].

This reinforces our hypothesis and confirms that there are significant ethnic differences regarding the soft tissue cephalometric standards. This variation must, therefore, be taken into account when setting the objectives of an orthodontic treatment. The present study has produced normative cephalometric data for a morocccan population that will help in diagnosis and treatment planning for patients requiring an orthodontic or an orthodontico surgical treatment.

\section{Conclusion}

The present work allows us to draw the following conclusions, male adolescents had an $\mathrm{H}$ angle greater than their female counterparts, There are differences between the Moroccan soft tissue profile standards and their American counterparts as set by Ricketts and Holdaway. Moroccans have a more important facial skin angle, $\mathrm{H}$ angle, bony convexity and Chin thickness compared to American standards. Clinically, this means that Moroccan adolescents with balanced feature shave a more convex profile compared to the normal profile of an American teenager.

So, a slight biprotrusion would be tolerated in our treatment objectives, as moroccan orthodontics.

\section{References}

[1]. ALBarakati SF, Bindayel NA. Holdaway soft tissue cephalometric standards for Saudi adults. King Saud Univ J Den Sci. 2012 Jan 1;3(1):27-32.

[2]. Park YC, Burstone CJ. Soft-tissue profile-fallacies of hard-tissue standards in treatment planning. Am J Orthod Dentofacial Orthop. 1986 Jul;90(1):5262. PubMed PMID: 3460347.

[3]. Angle EH. Treatment of malocclusion of the teeth: Angle's system. White Dental Manufacturing Company; 1907.

[4]. Holdaway RA. A soft-tissue cephalometric analysis and its use in orthodontic treatment planning. Part I. Am J Orthod. 1983 Jul;84(1):1-28. PubMed PMID: 6575614.

[5]. Holdaway RA. Changes in relationship of points A and B during orthodontic treatment. Am J Orthod. 1956 Mar 1;42(3):176-93.

[6]. Ricketts RM. Planning treatment on the basis of the facial pattern and an estimate of its growth. Angle Orthod. 1957 Jan;27(1):14-37.

[7]. Burstone CJ. Integumental contour and extension patterns. Angle Orthod. 1959 Apr;29(2):93-104.

[8]. Bousetta H, Gsir S, Martiniello M. Moroccan migrations towards Belgium and the European Union: crossed views. Universidad de Deusto; 2005.

[9]. Sachan A, Srivastav A, Chaturvedi TP. Soft-tissue cephalometric norms in a north Indian ethnic population. J Orthod Sci. 2012 Oct;1(4):92-7. doi: 10.4103/2278-0203.105877. PubMed PMID: 24987634.

[10]. Hamdan AM. Soft tissue morphology of Jordanian adolescents. Angle Orthod. 2010 Jan;80(1):80-5. doi: 10.2319/010809-17.1. PubMed PMID: 19852644.

[11]. Abu-Tayyem HM, Alshamsi AH, Hafez S, ElDin EM. Cephalometric norms for a sample of Emirates adults. Open J Stomatol. 2011 Sep 30;1(03):75.

[12]. Celebi AA, Tan E, Gelgor IE, Colak T, Ayyildiz E. Comparison of soft tissue cephalometric norms between Turkish and European-American adults. ScientificWorldJournal. 2013;2013:806203. doi: 10.1155/2013/806203. PubMed PMID: 23533362.

[13]. Atashi MH, Kachooei M. Soft tissue cephalometric standards based on NHP in a sample of Iranian adults. J Dent Res Dent Clin Dent Prospects. 2008 Spring;2(2):53-7. doi: 10.5681/joddd.2008.011. PubMed PMID: 23289059.

[14]. Taki AA, Oguz F, Abuhijleh E. Facial soft tissue values in Persian adults 
with normal occlusion and well-balanced faces. Angle Orthod. 2009 May;79(3):491-4. doi: 10.2319/020408-62.1. PubMed PMID: 19413374.

[15]. Hwang HS, Kim WS, McNamara Jr JA. Ethnic differences in the soft tissue profile of Korean and European-American adults with normal occlusions and well-balanced faces. Angle Orthod. 2002 Feb;72(1):72-80. PubMed PMID: 11843277

[16]. Alcalde RE, Jinno T, Orsini MG, Sasaki A, Sugiyama RM, Matsumura T. Soft tissue cephalometric norms in Japanese adults. Am J Orthod Dentofacial Orthop. 2000 Jul;118(1):84-9. PubMed PMID: 10893477.

[17]. Johannsdottir B, Thordarson A, Magnusson TE. Craniofacial skeletal and soft tissue morphology in Icelandic adults. Eur J Orthod. 2004 Jun;26(3):24550. PubMed PMID: 15222707.

[18]. Ebray EF, Caniklioglu CM, Ebray SK. Soft tissue profile in Anatolian Turkish adults: evaluation of horizontal lip position using different soft tissue analyses. Am J Orthod Dentofacial Orthop. 2002 Jan;121(1):57-64. PubMed PMID: 11786873.

[19]. Basciftci FA, Uysal T, Buyukerkmen A. Craniofacial structure of Anatolian Turkish adults with normal occlusions and well-balanced faces. Am J Orthod Dentofacial Orthop. 2004 Mar;125(3):366-72. PubMed PMID: 15014417.

[20]. Lahlou K, Bahoum A, Makhoukhi MB, Aalloula EH. Comparison of dentoalveolar protrusion values in Moroccans and other populations. Eur J Orthod. 2010 Aug;32(4):430-4. doi: 10.1093/ejo/cjp113. PubMed PMID: 20018796.

[21]. Moldez MA, Sato K, Sugawara J, Mitani H. Linear and angular filipino cephalometric norms according to age and sex. Angle Orthod. 2006 Sep;76(5):800-5. PubMed PMID: 17029513.

[22]. Behbehani F, Hicks EP, Beeman C, Kluemper GT, Rayens MK. Racial variations in cephalometric analysis between Whites and Kuwaitis. Angle Or- thod. 2006 May;76(3):406-11. PubMed PMID: 16637719.

[23]. N'Dindin-Guinan BA, Djaha K, Aka A, Faure J, Roux H. Evaluation of the facial esthetics in an Ivory Coast population. Odontostomatol Trop. 2000 Sep;23(91):15-22. PubMed PMID: 11372130.

[24]. Moate SJ, Darendeliler MA. Cephalometric norms for the Chinese: a compilation of existing data. Aust Orthod J. 2002 Mar;18(1):19-26. PubMed PMID: 12502125.

[25]. Abbassy MA, Horiuchi M, El Harouny N, Kanno Z, Ono T. Comparative cephalometric study of class I malocclusion in Egyptian and Japanese adult females. Orthod Waves. 2012 Jun 1;71(2):59-65.

[26]. Zhao XG, Hans MG, Palomo JM, Lin JX. Comparison of Chinese and white Bolton standards at age 13. Angle Orthod. 2013 Sep;83(5):809-16. doi: 10.2319/110412-849.1. PubMed PMID: 23368780.

[27]. Amini F, Razavian ZS, Rakhshan V. Soft tissue cephalometric norms of Iranian Class I adults with good occlusions and balanced faces. Int Orthod. 2016 Mar;14(1):108-22. doi: 10.1016/j.ortho.2015.12.003. PubMed PMID: 26853371.

[28]. Aziz AS, Ab Talib M, Alam MK, Basri R, Purmal K, Rahman SA. Linear and angular cephalometric lip morphology in Malaysian Chinese population. Int Med J. 2014 Feb 1;21(1):45-8.

[29]. Scavone Jr H, Zahn-Silva W, do Valle-Corotti KM, Nahás AC. Soft tissue profile in white Brazilian adults with normal occlusions and well-balanced faces. Angle Orthod. 2008 Jan;78(1):58-63. doi: 10.2319/103006-447.1. PubMed PMID: 18193966.

[30]. Kilic N, Catal G, Oktay H. McNamara norms for Turkish adolescents with balanced faces and normal occlusion. Aust Orthod J. 2010 May;26(1):33-7. PubMed PMID: 20575197. 